\title{
Religiosity and Impulsive Buying Tendencies: A model and Empirical Application
}

\author{
Muhammad Danish Habib ${ }^{1 *}$, Noshaba Batool ${ }^{2}$, Masood Hassan ${ }^{3}$ \\ ${ }^{1}$ Management Science, Air University, Aerospace and Aviation Campus, Kamra, Pakistan \\ ${ }^{2}$ Air University School of Management, Air University, Islamabad, Pakistan \\ ${ }^{3}$ College of Business Management (CBM), Institute of Business Management (IoBM), Karachi, Pakistan
}

\section{Keywords \\ Religiosity \\ Islam \\ Materialism \\ Life Satisfaction \\ Impulsive Buying Tendencies}

Received: 15 October 2019

Accepted: 25 April 2020

\begin{abstract}
Impulsive buying is a dream segment for retailers and marketers. Stimulants in retail environment evoke a sudden urge for the acquisition of products spontaneously. This desire for immediate possession and instant gratification may get an effect from the religious orientation and various beliefs of an individual. This study seeks to examine the influence of religiosity on impulsive buying behavior through various beliefs. Based on the theoretical assumption underpinning Values-Attitudes-Behavior (VAB) hierarchy and theory of consistency, this study examines religiosity as an antecedent of materialism, risk aversion, life satisfaction which ultimalty drive impulsive buying tendencies. A self-administrated survey questionnaire was used to collect the data by using mall-intercept approach. The sample size consisted of 272 consumers of apparel products. Structural equation modeling technique was carried out to establish the reliability, validity of measures and to examine the relational paths. In general, results are in support of propositions that the religiosity precedes various types of beliefs that turn into impulsive buying tendencies. Inner individual spiritual meanings and exterior social meaning of religious values condemn materialistic beliefs and enhance the risk aversion and life satisfaction of customers. Furthermore, customers with higher-level materialistic beliefs are more inclined towards impulsive tendencies, while the less risk-takers and satisfied with their life have lower impulsive tendencies. It requires incorporating the aspect of religious beliefs with behavioral outcomes. The findings of the study have significant implications for retailers of developing countries.
\end{abstract}

KAUJIE Classification: L41, L43, Q91

JEL Classification: E43, E44, G15, Z12

(C) 2020 JIBM. All rights reserved.

\footnotetext{
*Corresponding author: Muhammad Danish Habib and Masood Hassan (masoodhassan1@hotmail.com)

†Email: danish.habib87@gmail.com
} 


\section{INTRODUCTION}

Religion being a global phenomenon holds a fundamental place in defining social behaviors (Agarwala, Mishra, \& Singh, 2019). It is acknowledged as one of the most important cultural factors as it has significant contributions in shaping out the values, attitudes and behaviors of an individual as well as society (Mokhlis, 2009). A growing trend to examine the relationship between religiosity and consumption is observed in recent literature (Karoui \& Khemakhem, 2019). Initially, research on religion and consumption established that religious affiliations are significant predictors of consumption patterns (Agarwala et al., 2019; Al-Hyari, Alnsour, Al-Weshah, \& Haffar, 2012; Mathras, Cohen, Mandel, \& Mick, 2016). Later researchers postulated that religiosity is a strong predictor of consumer behavior as compared to religious affiliations (Choi, 2010).

Religiosity is defined as "the degree to which beliefs in specific religious values and ideals are held and practiced by an individual" (Delener, 1990). The construct of religiosity theoretically reflected that individual may be high on certain beliefs and values, but the difference is made through pursuit of those principles and internalization (Mokhlis, 2009). Despite the fact that more than $70 \%$ of the world being religious (Hunt \& Penwell, 2008), religious consumers are relatively understudied segment in marketing literature (Minton, 2019). Religiosity and consumer behavior have become a phenomenon to be reckoned with as it offers a significant amount of profits to the firms along with huge potential for future research (Agarwala et al., 2019; Dekhil, Boulebech, \& Bouslama, 2017).

The existing literature established that religiosity influences consumer evaluations about products and services (Mokhlis, 2009), pricing practices (Arli \& Tjiptono, 2018; Battour, Ismail, Battor, \& Awais, 2017) and promotions practices (Mansour \& Diab, 2016) of marketers. Furthermore, significant relationship was found between religiosity and behavioral outcomes like status-seeking (Yeniaras \& Akkemik, 2017), materialism (Agarwala et al., 2019) brand switching (Choi, 2010), risk aversion (Adhikari \& Agrawal, 2016), impulsiveness (Musadik \& Azmi, 2019), emotions and satisfaction (Nayebzadeh \& Jalaly, 2014).

Developing a clear insight into consumer behavior is a common goal of all practitioners and academicians (Bahrainizad \& Rajabi, 2018). Marketers are continuously involved in stimulating consumers during their purchase process to facilitate their decision making. Impulsive buying being a latent half of consumer behavior represents a sizeable amount of purchases (Habib \& Qayyum, 2018). Research studies revealed the fact that $70 \%$ of decisions are made at point of purchase (Hulten \& Vanyushyn, 2011). 30\% to 50\% of overall consumer buying is attributed to impulsive buying (Hausman, 2000). Ruvio and Belk (2013) noted that $62 \%$ of sales of supermarkets and $80 \%$ sales of luxury products are impulsive purchases. Increased tendencies in impulsive buying may have an adverse impact on consumers as it requires substantial amount of money, while it may also be associated with risk about the quality and functionality of the products (Liang, 2012). Previous studies have also reported that about $80 \%$ of the respondents had negative reviews about their impulsive purchase and were feeling regret about purchasing in that manner ( Harmancioglu, Zachary Finney, \& Joseph, 2009).

It is important to probe into impulsive buying tendency to develop a clear insight into its 
related aspects to counter the negative feelings (Bahrainizad \& Rajabi, 2018). The growing stream of literature on impulsive buying mainly focused on retail purchasing and found a number of contributing factors to impulsive buying. Generally, existing research regarding impulsive buying has consistently examined verity of individual factors and situational factors (Amos, Holmes, \& Keneson, 2014; Chan, Cheung, \& Lee, 2017). However, the marketing literature addressing impulsive buying behavior from religious context is relatively understudied (Musadik \& Azmi, 2019). Researchers call for further research to examine consumer decision making in context of religiosity (Agarwala et al., 2019; Bukhari et al., 2019; Islam \& Chandrasekaran, 2020). Muslim consumers are followers of common values that originate from their religious guidelines (Musadik \& Azmi, 2019). These guidelines serve as an important determinant in developing attitudes and subsequent behavior of Muslim consumers (Minton, 2019).

Religiosity being a part of sub-culture may affect the consumption practices of Pakistani consumers (Razzaq, Razzaq, Yousaf, \& Hong, 2018). Furthermore, a significant amount of Muslim population is represented by Young Muslims. It has been forecasted that by 2030, $60 \%$ of Muslims worldwide will be under the age of 30 (Islam \& Chandrasekaran, 2020). This market and its consumers with influence of their religion and distinct requirements have the potential to offer a unique study of impulse buying behavior. Thus this study attempted to model and empirically test impulsive buying tendencies in the context of religiosity. It has been found that customers find the consistency of the religious doctrine with their beliefs (Agarwala et al., 2019). Islamic doctrine asks its followers to follow a balanced approach in consumption and warns Muslims not to engage in spendthrift and extravagance behavior (Musadik \& Azmi, 2019). Thus Muslim consumers feel regret on their impulsive purchases and consider impulsive behavior to be wrong. In response to this problem, this study undertakes an empirical test for relationship between religiosity, materialism, risk aversion, life satisfaction and impulsive buying tendencies.

Some theoretical frameworks like VAB hierarchy (Homer \& Kahle, 1988) and theory of consistency (Peifer \& Holbert, 2016) provide grounds to place religiosity as potential determinant of impulsive buying tendencies. VAB theory suggested values as the base of consumer behavior cognitive hierarchy that may shape out behaviors through attitude (Kingston, 2016). Furthermore, in line with the consistency theory, customers are seeking consistency between values, attitude and behaviors (Raggiotto, Mason, \& Moretti, 2018). Applied these theoretical reflections in context of religisolity it can be proposed that religiosity precde towards materialism, risk aversion and life satisfaction that ultimately influence impulsive buying tendencies. A good understanding of Muslim consumers' buying behavior may equip marketers to deal with the negative feeling associated with the impulsive buying behavior.

\section{LITERATURE REVIEW}

\section{Religiosity and Impulse Buying Intention}

Authors have defined the "impulse buying intention" as a likelihood and measure of an individual's engaging in unplanned and sudden purchases (Chan et al., 2017; Rook, 1987; Rook \& Fisher, 1995). According to Ajzen and Fishbein (1988), individuals' wants can 
influence and control their behavior. Their model proposed an arbitrary class of behavior that is influenced by an individual's requirements and inclinations (Harmancioglu et al., 2009). Based on this model, Wilson and Liu (2011) further proposed a model which explained the role of Muslim's beliefs to risk aversion and emotional and rational decision making by Muslims. Recent studies also found a significant impact of religiosity on consumer behavior (Agarwala et al., 2019; Musadik \& Azmi, 2019). Islamic teachings recognize economic activities as a worship of the transactions that are performed as per Islamic principles. Muslims are supposed to follow the rules that are in line with Islamic doctrine (Musadik \& Azmi, 2019). They are also supposed to follow a balanced approach in their consumption patterns and avoid from wasteful and excessive consumption ( Ghani, Harjin, \& Ghani, 2008). Impulsive buying is recognized as the sudden and hedonically complex purchases which require instant ownership of an item (Attiq, 2015; Chan et al., 2017; Habib \& Qayyum, 2018). Rook (1987) postulated that different people show various tendencies for impulse buying. According to Jones and Lynam (2009), there are a variety of scales to evaluate the tendency of consumers' impulse buying. From the previous studies, it is therefore concluded that reasons for impulse buying are different in different people and it may also be affected by the lifestyle of individuals.

Religiosity describes the individual belief in God and commitment to perform life as per the principles set by God (Raggiotto et al., 2018). It is well established that religiosity influences individual's behavior including consumption behavior (Bukhari et al., 2019; Essoo $\&$ Dibb, 2004) and business behavior (Abuznaid, 2009; Wilson, 2006). Literature emphasized to conceptualize the complex nature of religiosity as a multidimensional construct (Lindridge, 2005; Mohd Dali, Yousafzai, \& Abdul Hamid, 2019). Minton, Kahle, Jiuan, and Tambyah, (2016), based on the model of Allport and Ross (1967), conceptualized the construct of religiosity as intrinsic religiosity and extrinsic religiosity. Intrinsic religiosity is related to personal objectives and describes inner spirituality objectives, while extrinsic religiosity describes social descriptions of individuals' religiousness (Arli \& Tjiptono, 2018; Vitell, Ramos-Hidalgo, \& RodrÃnguez-Rad, 2018). Further, religiosity is acknowledged as the predictor of behaviors and value systems (Hwang, 2018).

\section{Islamic Perspective on Impulsive Buying}

Islamic doctrine provides a balanced approach in consumption and warned Muslims not to engage in spendthrift and extravagant behavior (Musadik \& Azmi, 2019), where Qur'ān (6:14) states that Allah does not love those who do "israaf-excess in consumption of things that are otherwise permissible. Qur'ān, while prohibiting 'Tabzeer' firther says," .. for those who squander wastefully are Satan's brothers, and Satan is ever ungrateful to his Lord" (17:27) Tabzeer means spending for luxuries and sinful acts and similar things which are neither man's real necessities nor useful (Zaman, 2014). 'Israaf' and "Tabzeer' contradict the principles of "Wasatiyyah" or moderation which is much preached in Islam. According to the Islamic belief, excessive spending is forbidden in any mode and every individual must ensure moderation while fulfilling their needs (Rozana, Nugrahawati, \& Dwarawati, 2020). This principle of moderation applies to every course of action whether or not these acts involve 
money. The marketers, on the other hand, have not gained a clear insight about spending behaviour of Muslim consumers (Karoui \& Khemakhem, 2019). In recent era, issues related to the consumption of Muslim population are getting more attention, where the authorities are concerned about how pertinent decisions of Muslim consumers regarding finances are informed by their religious beliefs (Rozana et al., 2020).

\section{Religiosity and Islamic perspective}

Religion is recognized as a universal social institution that may shape out the believes, values, attitudes, and behaviors of individuals and society (Mokhlis, 2009). Religion is a distinct concept from religiosity. The former concept is the representation of the continuum of commitment towards a particular faith, while the latter concept is the representation of the emphasis of religion in guiding people to spend their life in accordance with religious teaching (Weaver \& Agle, 2002). Religiosity defines the way of life as a reflection of values and attitudes of individuals and societies (Fam et al., 2004). The people who believe in religion have certain values that may influence their decisions and actions. Islam is a religion that offers a complete guide to Muslims in every aspect of life, for instance how to trade, how to consume, what to eat and drink, etc ( Shah Alam, Mohd, \& Hisham, 2011). Islamic religiosity is based on Qur'ān and the Sunnah (Eid \& El-Gohary, 2015). Followers of Islamic religiosity are supposed to follow a balanced approach in every aspect of their life and avoid from wasteful and unnecessary consumptions (Ghani et al., 2008).

\section{Hypotheses Development Religiosity and Materialism}

Previous studies showed that religious consumers are less materialistic. Branded goods are least important for them and they avoid conspicuous consumption (Essoo \& Dibb, 2004; Stillman, Fincham, Vohs, Lambert, \& Phillips, 2012). Nevertheless, it is argued by some that religious consumers are not against materialism and lavishness (Arli \& Tjiptono, 2018). Therefore, it is inconsistent to conclude that people showing greater religious tendencies will rate low in materialistic behavior. Religious consumers may express low materialistic values because they have high subject wellbeing (Agarwala et al., 2019). Wellbeing is known as how individuals assess their life satisfaction on the rational and affective bases (La Barbera \& Gurhan, 1997). Individuals opt for materialism to cope with stress or unpleasant thoughts (Weaver \& Agle, 2002; Weaver, Moschis, \& Davis, 2011). Materialistic values lead to more unhappy and dissatisfied feelings as compared to non-materialistic values (Chang \& Arkin, 2002) and stress is strongly related to materialistic values (Weaver et al., 2011). Some studies also conclude that individuals who are practicing prayer in their daily lives are more satisfied and have a positive feeling about wellbeing of life. Prayer is defined as communication with the divine (Vasconcelos, 2010). Expressing gratitude help in energizing individuals and positively influence moods of people ( McCullough, Emmons, \& Tsang, 2002). This spiritual practice helps to reduce stress and control emotions of individuals (Watts 1996; Schimmel 1997). Accordingly customers with higher level of religious beliefs have lesser materialistic values. Thus, the researchers hypothesize: 
H1: Intrinsic religiosity has a significant and negative impact on materialism

H2: Extrinsic religiosity has a significant and negative impact on materialism

\section{Religiosity and Risk Aversion}

In a given situation, customers differ depending on the amount of risk they are willing to take. In general, risk-averse buyers hesitate to try new products, tend to keep on known brands and prevent behavioral changes (Matzler et al., 2008). An examination of the literature shows that the level of a consumer's religiosity is positive for aversion to risk. Religious teachings recommended a balanced consumption approach that may result in lessening impulsive purchases. Such consumers are more sensitive to risk perceptions in buying situations and experimental while shopping (Yousaf \& Shaukat Malik, 2013). They are reluctant to accept new products or change brands (Choi, 2010). It is postulated that religious customers' deep involvement in their religious group's standards and activities could create collectivistic tendencies or interdependence. "Experiencing interdependence entails seeing oneself as part of an encompassing social relationship and recognizing that one's behavior is determined, contingent on, and, to a large extent organized by what the actor perceives to be the thoughts, feelings, and actions of others in the relationship" (Markus \& Kitayama, 1991). Participants in any collective subculture field care for belonging and emphasize community laws which contribute to interdependence(Agarwala et al., 2019). The tightness of subcultures to which you belong is also connected with interdependency (Carpenter, 2000). A strong cultural group supports multiple rules and standards for its members and demands high standards of proper conduct (Gelfand, 2012). Religion being the subculture influence the aversion to risk positively. Accordingly, the researchers hypothesize:

H3: Intrinsic religiosity has a significant and positive impact on risk aversion

H4: Extrinsic religiosity has a significant and positive impact on risk aversion

\section{Religiosity and life satisfaction}

Religious significance advocates the claim that faith in "a devine other" and perceived closeness to God can lead to health through a sense of ontological trust and personal value that improves life satisfaction (Krause, 2004; Lim \& Putnam, 2010; Vang, Hou, \& Elder, 2019). As a potent force in shaping feelings of self-evolution and empowerment, Pollner (1989) points at interaction with " symbolic others"- in opposition to true congregational interactions. Accordingly, it is suggested that "divine relations" may not necessarily represent an "objective" truth strengthening our sense of coherence and order, thus reducing tension and guilt (Pollner, 1989). In contrast, a common faith reinforced by co-religionists shows that "attention and belief in divine causal significance are related to a sense of one another". Briefly, faith can help religious groups develop a sense of purpose and thus improve their happiness in their lives (Schieman, Bierman, \& Ellison, 2013). Some researchers have concluded that religious participation is a greater and more reliable association of well-being than the religion itself (Kortt, Dollery, \& Grant, 2015). For example, engagement in religious social activities was found to enhance the happiness of older, widowed white women for a better lifespan (Neill \& Kahn, 1999). Furthermore, it has been shown that participating in 
religious services is another important element of religion that affects well-being (Greenfield $\&$ Marks, 2007). Religious involvement often encourages contact with other congregations, thus creating a sense of identity that will be reinforced by "a shared set of beliefs, values and interests" (Schieman et al., 2013). Accordingly, it can be postulated that there is a positive impact of religiosity on risk aversion. Thus, the researchers hypothesize:

H5: Intrinsic religiosity has a significant and positive impact on life satisfaction H6: Extrinsic religiosity has a significant and positive impact on life satisfaction

\section{Materialism and Impulse Buying}

A strong link between materialism and impulse buying is shown in previous literature (Pradhan, Israel, \& Jena, 2018). People high on materialism and "loose" on money are predisposed to make "exhibitionist" transactions. It is argued that these customers would be both optimistic about debt and better about impulsive-buying. Dittmar, Beattie, and Friese (1995) found that individuals may buy an item impulsively to move their true selves closer to an imaginary (more ideal) themselves and that high-impulse purchases vary in terms of self-expression and work from low-impulse purchases. Lins et al., (2015) showed that the effect of impulsive purchases depends on reference or peer group's norms and values. A materialist who resides in a society in which material acquisition is the norm supposes that impulsive purchases could reflect prestige, leading to greater power. Participants of the peer group can even see a positive impact when the group views spontaneity and the pursuit of hedonic objectives favorably (Sharma, Sivakumaran, \& Marshall, 2010). Consequently it can be hypothesize that materialism has significant and positive impact on impulsive buying tendencies.

H7: Materialism has a significant and positive impact on impulsive buying tendencies

\section{Risk Aversion and Impulsive Buying}

The perceived risk can also be a significant constraint variable that could minimize the purchasing effect and avoid impulsive comportments by inducing resistance mechanisms or normative factors (Rook \& Fisher, 1995). Customers may behave more impulsively in a purchasing situation when they perceive a low risk (Lee \& Yi, 2008). A significant number of studies have shown that increased risk expectations regarding a brand decrease the desire of consumers to buy (Tifferet \& Herstein, 2012). Not surprisingly, the increased adverse repercussions of a product and the greater probability of these adverse events make the product less attractive to buyers. On the one hand, impulsive transactions are result of emotions and usually take place with reduced concern for effects (Mishra, Sinha, \& Koul, 2014). It would mean that the brand threat would play a limited role in such actions, as it would be a mental assessment of a situation and its implications. Empirical research suggests that impulse purchases were affected by cognitive issues, such as website value perceptions (Agag \& El-Masry, 2017; Akram et al., 2018) and expectations of online store (Chan et al., 2017; Chih, $\mathrm{Wu}, \& \mathrm{Li}, 2012$ ). Improved perception of brand risk can also inhibit impulsivity and rising impulse. Thus it can be postulated that risk aversion beliefs reduce impulsive buying tendencies. 
H8: Risk aversion has a significant and negative impact on impulsive buying tendencies.

\section{Life Satisfaction and Impulsive Buying Tendency}

Life satisfaction is characterized as an individual cognitive assessment in terms of quality of life. It is a wider term that encompasses a wide range of possibilities, such as poor living satisfaction, ordinary and average life satisfaction (or satisfaction with practical life) as well as complete satisfaction with life. Many surveys have measured the satisfaction of people with their lives based on their decisive role in the efficient functioning of personal and social life (Antaramian, Huebner, \& Valois, 2008). Ash and Huebner (2001) found demographic characteristics such as socioeconomic conditions as significant contributors of life satisfaction. Some research shows that people who are unhappy with their lives and feel that they are unwanted or uncomfortable, have depression sometimes; while sometimes, those who are reasonably happy to live, have symptoms of mental illness (Valois, Zullig, Huebner, \& Drane, 2009). Based on some research results, satisfaction with life is in a positive relationship with positive mental characteristics such as happiness and self-esteem. An individual's propensity to shop without a plan can be linked to effort for getting satisfaction in life (Silvera, Lavack, $\&$ Kropp, 2008). Thus it can be proposed that life satisfaction has a significant impact on impulsive buying tendencies.

H9: Life satisfaction has a significant and negative impact on impulsive buying tendencies.

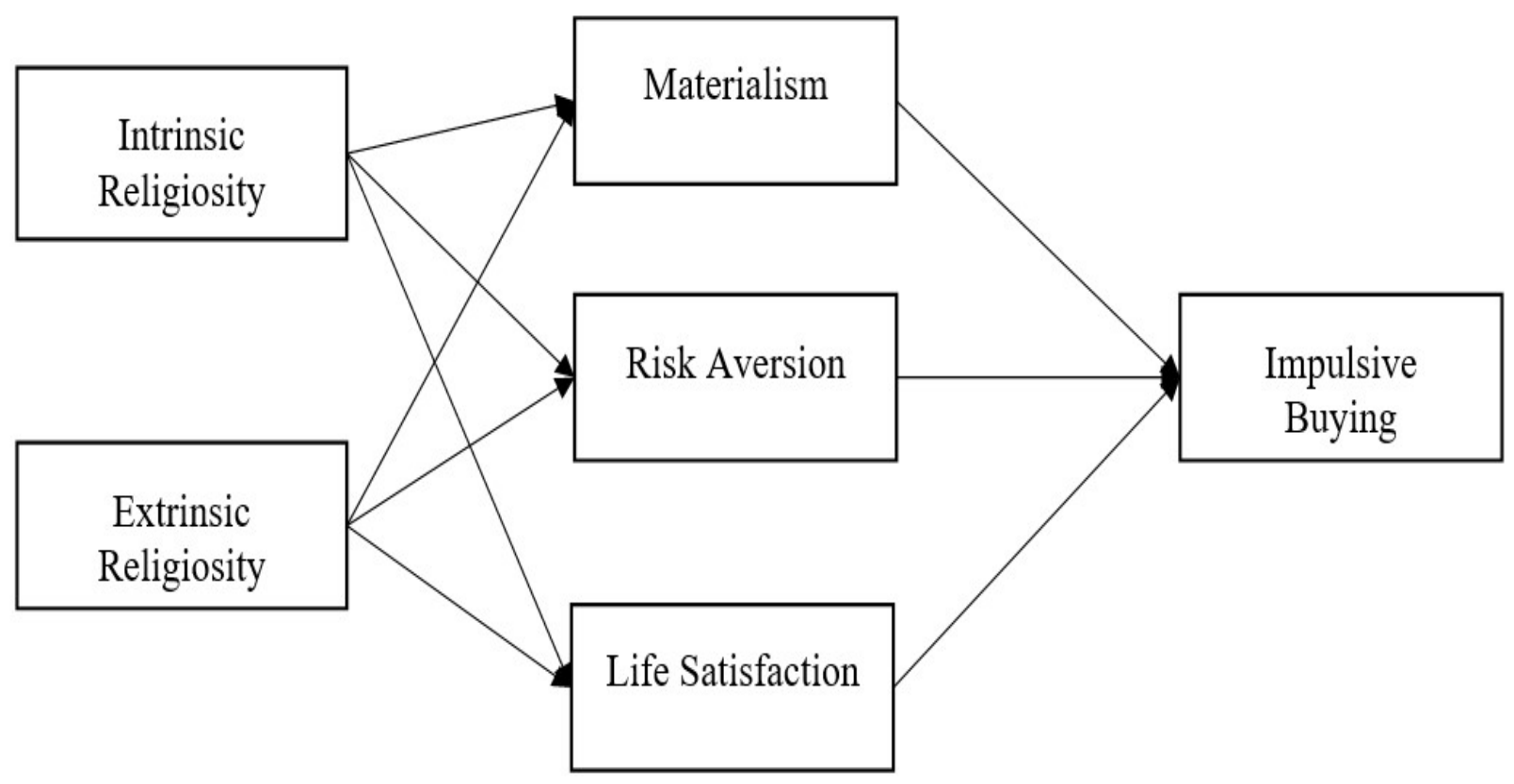

FIGURE 1. Theoretical framework

\section{RESEARCH METHODOLOGY}

The population of the study are buyers of apparel products (i.e. clothes, watches, and shoes, etc.). Mall intercept approach is used for the collection of data. Data is collected form 
different shopping malls of major cities (i.e. Islamabad, Rawalpindi, Lahore, Faisalabad, and Multan). During the data collection, researchers approached every 4th buyer of apparel products and asked him/her to fill out the questionnaire. A total of 410 questionnaires were distributed, out of which 313 were received. In the final study, 272 useable questionnaires were included. Respondents' profile is depicted in Table 1. Partial Least Square Structural Equation Modeling (PLS-SEM) technique was used to analyze the data. Hair et al. (2014) recommended two steps procedure for PLS-SEM. The first step is measurement model analysis and the second step is structural model analysis. SmartPLS 3.0 was used to analyze the data.

\section{Measures}

Survey questionnaire was based on well-established measures adopted from existing literature. To measure intrinsic religiosity, 5 items scale suggested by Allport and Ross (1967) was adapted, while to measure extrinsic religiosity, again Allport and Ross (1967) scale having 4 items was adapted. To measure materialism 8 items scale was adapted from Raggiotto et al. (2018). To measure risk aversion, 3 items scale suggested by Matzler, Grabner-Krauter, and Bidmon (2008) was adapted .Life satisfaction has been measured on 5 items scale by Diener, Oishi and Lucas (2003). To measure impulsive buying tendency, Nayebzadeh and Jalaly (2014) scale was adapted having 5 items. All responses have been taken on five points Likert scale.

TABLE 1

Profile of demographic variables

\begin{tabular}{|c|c|c|c|c|c|}
\hline Demographic & Category & Frequency & Mean (S.D) & Skewness & Kurtosis \\
\hline \multirow[t]{2}{*}{ Gender } & Male & 146 & 1 mode $(0.53)$ & 0.15 & -1.77 \\
\hline & Female & 126 & & & \\
\hline \multirow[t]{5}{*}{ Age (In years) } & Less than 20 & 13 & & & \\
\hline & $21-25$ & 75 & & & \\
\hline & $26-30$ & 83 & $2.98(1.03)$ & 0.32 & -0.86 \\
\hline & $31-35$ & 59 & & & \\
\hline & Above 35 & 42 & & & \\
\hline \multirow[t]{4}{*}{ Education } & Intermediate & 37 & $3.23(0.97)$ & -0.13 & -0.98 \\
\hline & Bachelor & 95 & & & \\
\hline & Masters & 76 & & & \\
\hline & Above Master & 52 & & & \\
\hline \multirow[t]{6}{*}{ Monthly Income } & Less than 50,000 & 21 & $3.88(0.98)$ & 0.43 & -1.34 \\
\hline & $50,001-100,000$ & 41 & & & \\
\hline & $100,001-150,000$ & 54 & & & \\
\hline & $150,001-200,000$ & 44 & & & \\
\hline & $200,001-250,000$ & 84 & & & \\
\hline & Above 250,000 & 28 & & & \\
\hline
\end{tabular}


TABLE 2

Results of Measurement Model Analysis

\begin{tabular}{|c|c|c|c|c|c|}
\hline Constructs & Items & Outer Loading & Cronbach's Alpha & Composite Reliability (CR) & $\mathrm{AVE}^{*}$ \\
\hline & INR1 & 0.69 & & & \\
\hline & INR2 & 0.73 & & & \\
\hline \multirow{3}{*}{$\begin{array}{l}\text { Intrinsic Reli- } \\
\text { giosity }\end{array}$} & INR3 & 0.81 & 0.81 & 0.87 & 0.57 \\
\hline & INR4 & 0.79 & & & \\
\hline & INR5 & 0.73 & & & \\
\hline \multirow{4}{*}{$\begin{array}{l}\text { Extrinsic Reli- } \\
\text { giosity }\end{array}$} & ExR1 & 0.74 & & & \\
\hline & ExR2 & 0.79 & 0.77 & 0.85 & 0.60 \\
\hline & ExR3 & 0.77 & & & \\
\hline & ExR4 & 0.78 & & & \\
\hline \multirow[t]{7}{*}{ Materialism } & Mat1 & 0.77 & 0.79 & 0.90 & 0.58 \\
\hline & Mat2 & 0.81 & & & \\
\hline & Mat3 & 0.78 & & & \\
\hline & Mat4 & 0.74 & & & \\
\hline & Mat5 & 0.75 & & & \\
\hline & Mat6 & 0.74 & & & \\
\hline & Mat7 & 0.71 & & & \\
\hline \multirow{3}{*}{ Risk Aversion } & RAv1 & 0.82 & 0.87 & 0.88 & 0.71 \\
\hline & RAv2 & 0.83 & & & \\
\hline & RAv3 & 0.87 & & & \\
\hline \multirow{4}{*}{ Life Satisfac- } & LST1 & 0.81 & 0.81 & 0.88 & 0.64 \\
\hline & LST2 & 0.84 & & & \\
\hline & LST3 & 0.79 & & & \\
\hline & LST4 & 0.75 & & & \\
\hline \multirow{5}{*}{$\begin{array}{l}\text { Impulsive Buy- } \\
\text { ing }\end{array}$} & IBT1 & 0.80 & 0.87 & 0.91 & 0.67 \\
\hline & IBT2 & 0.81 & & & \\
\hline & IBT3 & 0.83 & & & \\
\hline & IBT4 & 0.83 & & & \\
\hline & IBT5 & 0.80 & & & \\
\hline
\end{tabular}

* AVE: Average Extracted Variance

\section{Data Analysis}

\section{Measurement Model Analysis}

To analyze the measurement model, validity (i.e. convergent validity and discriminant validity) and reliability (i.e. Cronbach's alpha and composite reliability) have been measured. In measurement model analysis, factor loadings of observed variables are checked. Factor loadings showed the correlation among the observed variables with the latent variable. The resulting value should be higher than 0.50 and hence the observed variables having factor loading below 0.50 are deleted (i.e. Mat8 and LST5). The results are presented in Table 2. The internal consistency of latent variables was evaluated by using composite reliability and 
Cronbach alpha. Hair Jr, Hult, Ringle, and Sarstedt (2016) recommended that the value of composite reliability (CR) and Cronbach alpha should be higher than 0.70 . Average Variance Extracted (AVE) is used to understand convergent validity. To establish convergent validity, AVE value should be higher than 0.50 (Habib \& Saman, 2020; Hair Jr et al., 2016). The results of convergent validity are in Table 2 .

TABLE 3

Fornell-Larcker discriminant validity and correlation analysis

\begin{tabular}{lllllll}
\hline \hline Constructs & 1 & 2 & 3 & 4 & 5 & 6 \\
\hline 1. Intrinsic Religiosity & $\mathbf{0 . 7 5}$ & & & & & \\
2. Extrinsic Religiosity & 0.52 & $\mathbf{0 . 7 7}$ & & & & \\
3. Materialism & -0.56 & -0.42 & $\mathbf{0 . 7 6}$ & & & \\
4. Risk Aversion & 0.59 & 0.60 & -0.59 & $\mathbf{0 . 8 4}$ & & \\
5. Life Satisfaction & 0.71 & 0.56 & 0.53 & -0.59 & $\mathbf{0 . 8 0}$ & \\
6. Impulse Buying & -0.71 & -0.53 & 0.58 & -0.63 & -0.59 & $\mathbf{0 . 8 2}$ \\
\hline \hline
\end{tabular}

Fornell-Larcker criterion is used to test the discriminant validity. This criterion that matches the square root of AVE of all variables, should be greater than the inter constract correlation. Results are presented in Table 3 that exhibited that the square root of AVE of each latent variable is higher than their respective correlation values.

\section{Structural Model Analysis}

Following the measurement analysis, structural model analysis is performed. In structural model assessment, structural path analysis and R2 analysis are performed. To analyze the hypotheses of the study, the structural model has been analyzed. First hypothesis results showed that intrinsic religiosity negatively influences the materialism of the consumers (i.e. $\beta=-0.47, p<0.00$ ). Second hypothesis results also showed that extrinsic religiosity negatively influenced the materialism of the consumers (i.e. $\beta=-0.17, p<0.00$ ). Third hypothesis result show that intrinsic religiosity positively influences the risk aversion (i.e. $\beta=0.39, p<0.00$ ). Forth hypothesis result show that extrinsic religiosity positively influences the risk aversion (i.e. $\beta=0.39, p<0.00$ ). Fifth hypothesis result show that intrinsic religiosity positively influences the life satisfaction (i.e. $\beta=0.58, p<0.00$ ). Sixth hypothesis result show that extrinsic religiosity positively influences the life satisfaction (i.e. $\beta=0.26, p<0.00$ ). Seventh hypothesis result show that materialism positively influences impulsive buying tendency (i.e. $\beta=0.29, p<0.00$ ). Eighth hypothesis result show that risk aversion negatively influences the impulsive buying tendency (i.e. $\beta=-0.36, p<0.00$ ). Ninth hypothesis result imply that life satisfaction negatively influences the impulsive buying tendency (i.e. $\beta=-0.24, p<0.00$ ). The results are given in Table 4. 
TABLE 4

Results of structural model

\begin{tabular}{llll}
\hline \hline Hypothesis & Path & $\beta$ & $p$-value \\
\hline H1 & Int Religious $\rightarrow$ Materialism & -0.47 & 0.00 \\
H2 & Ext Religious $\rightarrow$ Materialism & -0.17 & 0.01 \\
H3 & Int Religious $\rightarrow$ Risk Avers & 0.39 & 0.00 \\
H4 & Ext Religious $\rightarrow$ Risk Avers & 0.39 & 0.00 \\
H5 & Int Religious $\rightarrow$ Life Satisfaction & 0.58 & 0.00 \\
H6 & Ext Religious $\rightarrow$ Life Satisfaction & 0.26 & 0.00 \\
H7 & Materialism $\rightarrow$ Imp. Buy Tendency & 0.29 & 0.00 \\
H8 & Risk Avers $\rightarrow$ Imp. Buy Tendency & -0.36 & 0.00 \\
H9 & Life Satisfaction $\rightarrow$ Imp. Buy Tendency & -0.24 & 0.00 \\
\hline \hline
\end{tabular}

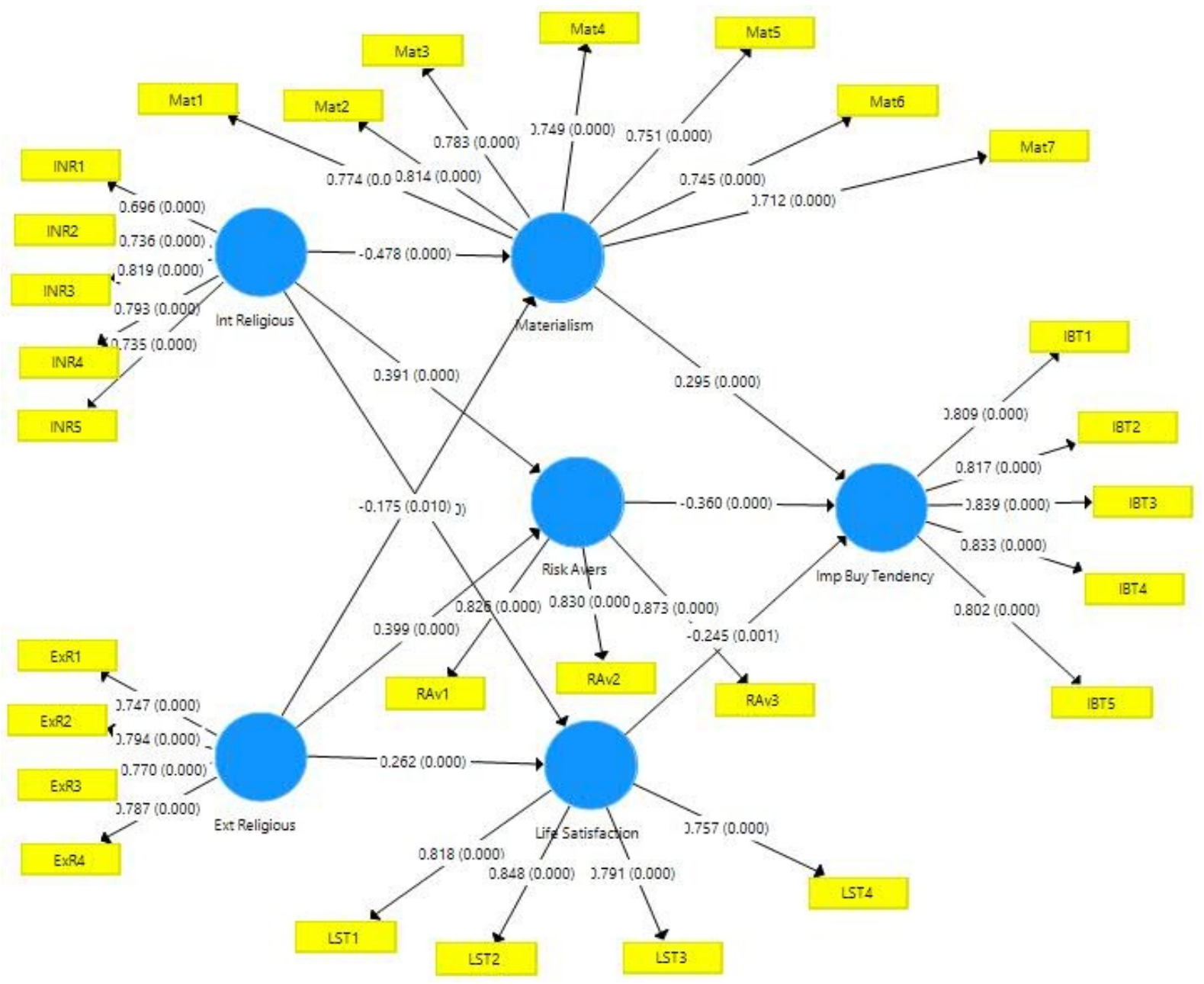

FIGURE 2. Structural Model

To measure that how much data is close to the fitted regression line, R2 analysis is performed. $R^{2}$ values lie among 0 and 1 . High value represents a good model fit of data. The 
values of $\mathrm{R} 2$ for materialism is 0.34 , risk aversion is 0.47 , life satisfaction is 0.56 , and for impulsive buying tendency is 0.54 . The results are given in Table 5 .

TABLE 5

\begin{tabular}{ll}
\multicolumn{2}{c}{ Results of structural model } \\
\hline \hline Constructs & $R^{2}$ \\
\hline Materialism & 0.34 \\
Risk Aversion & 0.47 \\
Life Satisfaction & 0.56 \\
Impulsive Buying Tendency & 0.54 \\
\hline \hline
\end{tabular}

\section{Discussion}

This study provides a theoretical mechanism through which religious beliefs are transformed into materialism, risk aversion and life satisfaction that precede the impulsive buying tendencies. The findings of the study are in line with the assumptions of VAB and the theory of consistency (Homer \& Kahle, 1988; Kingston, 2016; Peifer\& Holbert, 2016; Raggiotto et al., 2018). The findings showed that customers follow their religious doctrine in their consumption pattrens (Agarwala et al., 2019). The results reveal that religious values weaken the materialistic beliefs, and strengthen the risk aversion and life satisfaction of consumers. Findings support the proposition that religion has a significant influence on material life (Rahman et al., 2017). Both inner / individual spiritual meanings and exterior/ social meaning of religiousness condemn materialistic possession. Accordingly, materialism is in contrast to the values of religiosity and opposes the teaching of balanced and antithetical consumption. The results also validate the proposition that religious customers are more sensitive towards risk and are less likely to experience risk (Bukhari et al., 2019; Yousaf \& Shaukat Malik, 2013). Customers with the deep involvement of religiousness have interdependence and avoid experiencing new technology and products. Furthermore, results show that religious consumers are more satisfied with normal matters of life (Nayebzadeh \& Jalaly, 2014).

The results also revealed that consumers with materialistic beliefs tend to acquire more goods and would be buying excessively without evaluating the consequences of the purchases. Furthermore, results also support that customers with low-level risk-taking attitude avoid purchasing the new products and experimentations. Thus, before buying they are inclined to review their purchases and evaluate the consequences the risk involved. Results also support that life satisfaction is aligned with mental and physical health (Valois et al., 2009). Life satisfaction has a positive relation with positive mental features and is adversely related to depression. Purchasing without a plan is the depiction of negative mental health (Silvera et al., 2008). So, the results validate that the customers with higher level of life satisfaction are less inclined towards impulsive purchases.

There are some notable limitations, in terms of the generalizability and interpretation of the results. The data was collected from mall customers of apparel products and therefore results are not generalizable to other product categories and online settings. Further research 
should consider the other product categories and diverse online settings to enhance the generalizability of results. The actual behaviors may also provide meaningful results in the context of the proposed model. The findings also suffer from sampling approach and geographical area. Of course, this model can also be tested by using a rigorous sampling technique on diverse samples and geographical locations.

\section{CONCLUSION}

The current study has extended the applicability of VAB and the theory of consistency by examining it in the context of religiosity. VAB and theory of consistency provide a comprehensive assessment of impulsive buying tendencies of Muslim consumers of Pakistan. The study operationalizes the concept of religiosity as intrinsic and extrinsic to comprehend the complex nature of the concept. In line with the VAB, findings support the proposition that intrinsic as well as extrinsic religious values significantly contribute towards cognitive aspect (materialism, risk aversion, life satisfaction) that ultimately influence consumption behavior (impulsive buying tendencies). Consistent with theory of consistency, the study found that customers find the consistency of the religious doctrines with their beliefs. The results also revealed that Muslim consumers follow a balanced approach in their consumption patterns and avoid from wasteful and extravagant consumption.

\section{REFERENCES}

Abuznaid, S. A. (2009). Business ethics in Islam: The glaring gap in practice. International Journal of Islamic and Middle Eastern Finance and Management, 2(4), 278-288. doi: https://doi.org/10.1108/17538390911006340

Adhikari, B. K., \& Agrawal, A. (2016). Does local religiosity matter for bank risk-taking? Journal of Corporate Finance, 38, 272-293.

doi: https://doi.org/10.1016/j.jcorpfin.2016.01.009

Agag, G. M., \& El-Masry, A. A. (2017). Why do consumers trust online travel websites?

Drivers and outcomes of consumer trust toward online travel websites. Journal of Travel Research, 56(3), 347-369. doi: https://doi.org/10.1177/0047287516643185

Agarwala, R., Mishra, P., \& Singh, R. (2019). Religiosity and consumer behavior: A summarizing review. Journal of Management, Spirituality $\mathcal{E}$ Religion, 16(1), 32-54. doi: https://doi.org/10.1080/14766086.2018.1495098

Ajzen, I., \& Fishbein, M. (1988). Theory of reasoned action-Theory of planned behavior. University of South Florida.

Akram, U., Hui, P., Kaleem Khan, M., Tanveer, Y., Mehmood, K., \& Ahmad, W. (2018). How website quality affects online impulse buying: Moderating effects of sales promotion and credit card use. Asia Pacific Journal of Marketing and Logistics, 30(1), 235-256. doi: https://doi.org/10.1108/APJML-04-2017-0073

Al-Hyari, K., Alnsour, M., Al-Weshah, G., \& Haffar, M. (2012). Religious beliefs and consumer behaviour: From loyalty to boycotts. Journal of Islamic Marketing, 3(2), 155-174. doi: https://doi.org/10.1108/17590831211232564 
Allport, G. W., \& Ross, J. M. (1967). Personal religious orientation and prejudice. Journal of Personality and Social Psychology, 5(4), 432-443.

doi: https://doi.org/10.1037/h0021212

Amos, C., Holmes, G. R., \& Keneson, W. C. (2014). A meta-analysis of consumer impulse buying. Journal of Retailing and Consumer Services, 21(2), 86-97. doi: https://doi.org/10.1016/j.jretconser.2013.11.004

Antaramian, S. P., Huebner, E. S., \& Valois, R. F. (2008). Adolescent life satisfaction. Applied Psychology, 57, 112-126. doi: https://doi.org/10.1111/j.1464-0597.2008.00357.x

Arli, D. I., \& Tjiptono, F. (2018). Consumer Ethics, Religiosity, and Consumer Social Responsibility: Are They Related? Social Responsibility Journal, 14(2), 302-320. doi: https://doi.org/10.1108/SRJ-03-2016-0036

Ash, C., \& Huebner, E. S. (2001). Environmental events and life satisfaction reports of adolescents: A test of cognitive mediation. School Psychology International, 22(3), 320-336. doi: https://doi.org/10.1177/0143034301223008

Attiq, S. (2015). Attention to Social Comparison Information and Compulsive Buying Behavior: An SOR Analysis. Journal of Behavioural Sciences, 25(1), 39-58.

Bahrainizad, M., \& Rajabi, A. (2018). Consumers' perception of usability of product packaging and impulse buying: Considering consumers' mood and time pressure as moderating variables. Journal of Islamic Marketing, 9(2), 262-282. doi: https://doi.org/10.1108/JIMA-04-2016-0030

Battour, M., Ismail, M. N., Battor, M., \& Awais, M. (2017). Islamic tourism: An empirical examination of travel motivation and satisfaction in Malaysia. Current Issues in Tourism, 20(1), 50-67. doi: https://doi.org/10.1080/13683500.2014.965665

Bukhari, S. F. H., Woodside, F. M., Hassan, R., Shaikh, A. L., Hussain, S., \& Mazhar, W. (2019). Is religiosity an important consideration in Muslim consumer behavior: Exploratory study in the context of western imported food in Pakistan. Journal of Islamic Marketing, 10(4), 1288-1307. doi: https://doi.org/10.1108/JIMA-01-2018-0006

Chan, T. K., Cheung, C. M., \& Lee, Z. W. (2017). The state of online impulse-buying research: A literature analysis. Information $\mathcal{E}$ Management, 54(2), 204-217. doi: https://doi.org/10.1016/j.im.2016.06.001

Chang, L., \& Arkin, R. M. (2002). Materialism as an attempt to cope with uncertainty. Psychology E Marketing, 19(5), 389-406. doi: https://doi.org/10.1002/mar.10016

Chih, W.-H., Wu, C. H.-J., \& Li, H.-J. (2012). The antecedents of consumer online buying impulsiveness on a travel website: Individual internal factor perspectives. Journal of Travel $\mathcal{E}$ Tourism Marketing, 29(5), 430-443.

doi: https://doi.org/10.1080/10548408.2012.691393

Choi, Y. (2010). Religion, religiosity, and South Korean consumer switching behaviors. Journal of Consumer Behaviour, 9(3), 157-171. doi: https://doi.org/10.1002/cb.292

Dekhil, F., Boulebech, H., \& Bouslama, N. (2017). Effect of religiosity on luxury consumer behavior: The case of the Tunisian Muslim. Journal of Islamic Marketing, 8(1), 74-94. doi: https://doi.org/10.1108/JIMA-09-2012-0051 
Delener, N. (1990). The effects of religious factors on perceived risk in durable goods purchase decisions. Journal of Consumer Marketing, 7(3), 27-38.

doi: https://doi.org/10.1108/EUM0000000002580

Diener, E., Oishi, S., \& Lucas, R. E. (2003). Personality, culture, and subjective wellbeing: Emotional and cognitive evaluations of life. Annual Review of Psychology, 54(1), 403-425. doi: https://doi.org/10.1146/annurev.psych.54.101601.145056

Dittmar, H., Beattie, J., \& Friese, S. (1995). Gender identity and material symbols: Objects and decision considerations in impulse purchases. Journal of Economic Psychology, 16(3), 491-511. doi: https://doi.org/10.1016/0167-4870(95)00023-H

Eid, R., \& El-Gohary, H. (2015). The role of Islamic religiosity on the relationship between perceived value and tourist satisfaction. Tourism Management, 46, 477-488. doi: https://doi.org/10.1016/j.tourman.2014.08.003

Essoo, N., \& Dibb, S. (2004). Religious influences on shopping behaviour: An exploratory study. Journal of Marketing Management, 20(7-8), 683-712. doi: https://doi.org/10.1362/0267257041838728

Fam, K. S., Waller, D. S., \& Erdogan, B. Z. (2004). The influence of religion on attitudes towards the advertising of controversial products. European Journal of Marketing, $38(5 / 6), 537-555$.

Gelfand, M. J. (2012). Culture's constraints: International differences in the strength of social norms. Current Directions in Psychological Science, 21(6), 420-424. doi: https://doi.org/10.1177/0963721412460048

Ghani, B. A., Harjin, A. A., \& Ghani, S. A. (2008). Konsep Penggunaan dari Perspektif Ekonomi Islam. Seminar Keusahawanan Islam II Peringkat Kebangsaan. Kaula Lampur, Malaysia: University of Malaya.

Greenfield, E. A., \& Marks, N. F. (2007). Religious social identity as an explanatory factor for associations between more frequent formal religious participation and psychological well-being. The International Journal for the Psychology of Religion, 17(3), 245-259. doi: https://doi.org/10.1080/10508610701402309

Habib, M. D., \& Qayyum, A. (2018). Cognitive emotion theory and emotion-action tendency in online impulsive buying behavior. Journal of Management Sciences, 5(1), 86-99. doi: https://doi.org/10.20547/jms.2014.1805105

Habib, M. D., \& Saman, A. (2020). A model and empirical examination of influencing factors of customer satisfaction and service performance through interactional quality. Business E Economic Review, 12(1), 119-138. doi: https://doi.org/dx.doi.org/10.22547/BER/12.1.6

Hair Jr, J. F., Hult, G. T. M., Ringle, C., \& Sarstedt, M. (2016). A primer on partial least squares structural equation modeling (PLS-SEM). Thousand Oaks, CA: Sage publications. doi: https://doi.org/10.15358/9783800653614

Harmancioglu, N., Zachary Finney, R., \& Joseph, M. (2009). Impulse purchases of new products: An empirical analysis. Journal of Product $\mathcal{E}$ Brand Management, 18(1), 27-37. doi: https://doi.org/10.1108/10610420910933344 
Hausman, A. (2000). A multi-method investigation of consumer motivations in impulse buying behavior. Journal of Consumer Marketing, 17(5), 403-426.

doi: https://doi.org/10.1108/07363760010341045

Homer, P. M., \& Kahle, L. R. (1988). A structural equation test of the value-attitudebehavior hierarchy. Journal of Personality and Social Psychology, 54(4), 638-646. doi: https://doi.org/10.1037/0022-3514.54.4.638

Hulten, P., \& Vanyushyn, V. (2011). Impulse purchases of groceries in France and Sweden. Journal of Consumer Marketing, 28(5), 376-384. doi: https://doi.org/10.1108/07363761111150026

Hunt, J., \& Penwell, D. (2008). AMG's handi-reference world religions and cults. Chattanooga, TN: AMG Publishers.

Hwang, H. (2018). Do religion and religiosity affect consumers' intentions to adopt proenvironmental behaviours? International Journal of Consumer Studies, 42(6), 664-674. doi: https://doi.org/10.1111/ijcs.12488

Islam, T., \& Chandrasekaran, U. (2020). Religiosity and consumer decision making styles of young Indian Muslim consumers. Journal of Global Scholars of Marketing Science, 30(2), 147-169. doi: https://doi.org/10.1080/21639159.2019.1679031

Jones, S., \& Lynam, D. R. (2009). In the eye of the impulsive beholder: The interaction between impulsivity and perceived informal social control on offending. Criminal Justice and Behavior, 36(3), 307-321. doi: https://doi.org/10.1177/0093854808328653

Karoui, S., \& Khemakhem, R. (2019). Factors affecting the Islamic purchasing behavior-A qualitative study. Journal of Islamic Marketing, 10(4), 1104-1127.

doi: https://doi.org/10.1108/JIMA-12-2017-0145

Kingston, T. (2016). Cute, Creepy, or Crispy-How values, attitudes, and norms shape human behavior toward bats. In V. C. Christian, \& T. Kingston (Eds.) Bats in the Anthropocene: Conservation of Bats in a changing world. New York, NY: Springer International. doi: https://doi.org/10.1007/978-3-319-25220-9_18

Kortt, M. A., Dollery, B., \& Grant, B. (2015). Religion and life satisfaction down under. Journal of Happiness Studies, 16(2), 277-293. doi: https://doi.org/10.1007/s10902-0149509-4

Krause, N. (2004). Common facets of religion, unique facets of religion, and life satisfaction among older African Americans. The Journals of Gerontology Series B: Psychological Sciences and Social Sciences, 59(2), S109-S117.

doi: https://doi.org/10.1093/geronb/59.2.S109

La Barbera, P. A., \& Gurhan, Z. (1997). The role of materialism, religiosity, and demographics in subjective well-being. Psychology $\mathcal{F}$ Marketing, 14(1), 71-97.

Lee, G. Y., \& Yi, Y. (2008). The effect of shopping emotions and perceived risk on impulsive buying: The moderating role of buying impulsiveness trait. Seoul Journal of Business, 14(2), 68-92.

Liang, Y.-P. (2012). The relationship between consumer product involvement, product knowledge and impulsive buying behavior. Procedia-Social and Behavioral Sciences, 57, 325-330. doi: https://doi.org/10.1016/j.sbspro.2012.09.1193 
Lim, C., \& Putnam, R. D. (2010). Religion, social networks, and life satisfaction. American Sociological Review, 75(6), 914-933. doi: https://doi.org/10.1177/0003122410386686 Lindridge, A. (2005). Religiosity and the construction of a cultural-consumption identity. Journal of Consumer Marketing, 22(3), 142-151. doi: https://doi.org/10.1108/07363760510595968

Lins, S., Doka, A., Bottequin, E., Odabasic, A., Pavlovic, S., Merchan, A., Golasa, A., \& Hylander, F. (2015). The effects of having, feeling, and thinking on impulse buying in european adolescents. Journal of International Consumer Marketing, 27(5), 414-428. doi: https://doi.org/10.1080/08961530.2015.1027028

Mansour, I. H. F., \& Diab, D. M. E. (2016). The relationship between celebrities' credibility and advertising effectiveness. Journal of Islamic Marketing, 7(2), 148-166.

Markus, H. R., \& Kitayama, S. (1991). Culture and the self: Implications for cognition, emotion, and motivation. Psychological Review, 98(2), 224-253.

doi: https://doi.org/10.1037/0033-295X.98.2.224

Mathras, D., Cohen, A. B., Mandel, N., \& Mick, D. G. (2016). The effects of religion on consumer behavior: A conceptual framework and research agenda. Journal of Consumer Psychology, 26(2), 298-311. doi: https://doi.org/10.1016/j.jcps.2015.08.001

Matzler, K., Grabner-Krauter, S., \& Bidmon, S. (2008). Risk aversion and brand loyalty: The mediating role of brand trust and brand affect. Journal of Product $\mathcal{E}$ Brand Management, 17(3), 154-162.

McCullough, M. E., Emmons, R. A., \& Tsang, J.-A. (2002). The grateful disposition: A conceptual and empirical topography. Journal of Personality and Social Psychology, 82(1), 112-127. doi: https://doi.org/10.1037/0022-3514.82.1.112

Minton, E. A. (2019). Believing is buying: Religiosity, advertising skepticism, and corporate trust. Journal of Management, Spirituality $\mathcal{E}$ Religion, 16(1), 54-75. doi: https://doi.org/10.1080/14766086.2018.1437764

Minton, E. A., Kahle, L. R., Jiuan, T. S., \& Tambyah, S. K. (2016). Addressing Criticisms of Global Religion Research: A Consumption-Based Exploration of Status and Materialism, Sustainability, and Volunteering Behavior. Journal for the Scientific Study of Religion, 55(2), 365-383. doi: https://doi.org/10.1111/jssr.12260

Mishra, H. G., Sinha, P. K., \& Koul, S. (2014). Buying Impulsive Trait. Journal of Management Research, 14(2), 109-120. doi:

Mohd Dali, N. R. S., Yousafzai, S., \& Abdul Hamid, H. (2019). Religiosity scale development. Journal of Islamic Marketing, 10(1), 227-248. doi: https://doi.org/10.1108/JIMA11-2016-0087

Mokhlis, S. (2009). Relevancy and measurement of religiosity in consumer behavior research. International Business Research, 2(3), 75-84. doi: https://doi.org/10.5539/ibr.v2n3p75

Musadik, S. H. S. A., \& Azmi, I. A. G. (2019). Impulse buying behaviour from islamic perspective: A conceptual paper. In M. S. Noor Zahirah, S. Roshima, \& W. H. Wan Norhaniza (Eds.), Islamic Development Management recent advancement and issues (pp. 161-172). Singapore: Springer. doi: https://doi.org/10.1007/978-981-13-7584-2_12 
Nayebzadeh, S., \& Jalaly, M. (2014). Investigating Iranian female Muslim consumer impulse buying behaviour used as a form of retail therapy. Journal of Islamic Marketing, 5(2), 302-320. doi: https://doi.org/10.1108/JIMA-05-2012-0029

Neill, C. M., \& Kahn, A. S. (1999). The role of personal spirituality and religious social activity on the life satisfaction of older widowed women. Sex Roles, 40(3-4), 319-329. doi: https://doi.org/10.1023/A:1018811324286

Peifer, J. T., \& Holbert, R. L. (2016). Appreciation of pro-attitudinal versus counterattitudinal political humor: A cognitive consistency approach to the study of political entertainment. Communication Quarterly, 64(1), 16-35. doi: https://doi.org/10.1080/01463373.2015.1078828

Pollner, M. (1989). Divine relations, social relations, and well-being. Journal of Health and Social Behavior, 30(1), 92-104. doi: https://doi.org/10.2307/2136915

Pradhan, D., Israel, D., \& Jena, A. K. (2018). Materialism and compulsive buying behaviour: The role of consumer credit card use and impulse buying. Asia Pacific Journal of Marketing and Logistics, 30(5), 1239-1258.

doi: https://doi.org/10.1108/APJML-08-2017-0164

Raggiotto, F., Mason, M. C., \& Moretti, A. (2018). Religiosity, materialism, consumer environmental predisposition. Some insights on vegan purchasing intentions in Italy. International Journal of Consumer Studies, 42(6), 613-626.

doi: https://doi.org/10.1111/ijcs.12478

Rahman, M., Albaity, M., \& Maruf, B. (2017). The role of religiosity on the relationship between materialism and fashion clothing consumption among Malaysian Generation Y consumers. Social Indicators Research, 132(2), 757-783.

doi: https://doi.org/10.1007/s11205-016-1310-9

Razzaq, Z., Razzaq, A., Yousaf, S., \& Hong, Z. (2018). The impact of utilitarian and hedonistic shopping values on sustainable fashion consumption: The moderating role of religiosity. Global Business Review, 19(5), 1224-1239.

doi: https://doi.org/10.1177/0972150918777947

Rook, D. W. (1987). The buying impulse. Journal of Consumer Research, 14(2), 189-199. doi: https://doi.org/10.1086/209105

Rook, D. W., \& Fisher, R. J. (1995). Normative influences on impulsive buying behavior. Journal of Consumer Research, 22(3), 305-313. doi: https://doi.org/10.1086/209452

Rozana, A., Nugrahawati, E. N., \& Dwarawati, D. (2020). Effect of Gratitude and Self Control to Impulsive Buying in Unisba Students. 2nd Social and Humaniora Research Symposium (SoRes 2019), Bandung, Indonesia.

doi: https://doi.org/10.2991/assehr.k.200225.099

Ruvio, A. A., \& Belk, R. W. (2013). The Routledge companion to identity and consumption. Abingdon, UK: Routledge. doi:

Schieman, S., Bierman, A., \& Ellison, C. G. (2013). Religion and mental health. In Handbook of the sociology of mental health (pp. 457-478). New York, NY: Springer. doi: https://doi.org/10.1007/978-94-007-4276-5_22 
Shah Alam, S., Mohd, R., \& Hisham, B. (2011). Is religiosity an important determinant on Muslim consumer behaviour in Malaysia? Journal of Islamic Marketing, 2(1), 83-96. doi: https://doi.org/10.1108/17590831111115268

Sharma, P., Sivakumaran, B., \& Marshall, R. (2010). Impulse buying and variety seeking: A trait-correlates perspective. Journal of Business Research, 63(3), 276-283. doi: https://doi.org/10.1016/j.jbusres.2009.03.013

Silvera, D. H., Lavack, A. M., \& Kropp, F. (2008). Impulse buying: The role of affect, social influence, and subjective wellbeing. Journal of Consumer Marketing, 25(1), 23-33. doi: https://doi.org/10.1108/07363760810845381

Stillman, T. F., Fincham, F. D., Vohs, K. D., Lambert, N. M., \& Phillips, C. A. (2012). The material and immaterial in conflict: Spirituality reduces conspicuous consumption. Journal of Economic Psychology, 33(1), 1-7.

doi: https://doi.org/10.1016/j.joep.2011.08.012

Tifferet, S., \& Herstein, R. (2012). Gender differences in brand commitment, impulse buying, and hedonic consumption. Journal of Product $\mathcal{E}$ Brand Management, 21(3), 176-182. doi: https://doi.org/10.1108/10610421211228793

Valois, R. F., Zullig, K. J., Huebner, E. S., \& Drane, J. W. (2009). Youth developmental assets and perceived life satisfaction: Is there a relationship? Applied Research in Quality of Life, 4(4), 315-331. doi: https://doi.org/10.1007/s11482-009-9083-9

Vang, Z. M., Hou, F., \& Elder, K. (2019). Perceived religious discrimination, religiosity, and life satisfaction. Journal of Happiness Studies, 20(6), 1913-1932. doi: https://doi.org/10.1007/s10902-018-0032-x

Vasconcelos, A. F. (2010). The effects of prayer on organizational life: A phenomenological study. Journal of Management $\mathcal{E}$ Organization, 16(3), 369-381. doi: https://doi.org/10.1017/S1833367200002029 https://doi.org/10.5172/jmo.16.3.369

Vitell, S., Ramos-Hidalgo, E., \& RodrÃgguez-Rad, C. (2018). A Spanish perspective on the impact on religiosity and spirituality on consumer ethics. International Journal of Consumer Studies, 42(6), 675-686. doi: https://doi.org/10.1111/ijcs.12438

Weaver, G. R., \& Agle, B. R. (2002). Religiosity and ethical behavior in organizations: A symbolic interactionist perspective. Academy of Management Review, 27(1), 77-97. doi: https://doi.org/10.5465/amr.2002.5922390 https://doi.org/10.2307/4134370

Weaver, S. T., Moschis, G. P., \& Davis, T. (2011). Antecedents of materialism and compulsive buying: A life course study in Australia. Australasian Marketing Journal (AMJ), 19(4), 247-256. doi: https://doi.org/10.1016/j.ausmj.2011.04.007

Wilson, J. A., \& Liu, J. (2011). The challenges of Islamic branding: Navigating emotions and halal. Journal of Islamic Marketing, 2(1), 28-42.

doi: https://doi.org/10.1108/17590831111115222

Wilson, R. (2006). Islam and business. Thunderbird International Business Review, 48(1), 109-123. doi: https://doi.org/10.1002/tie.20088

Yeniaras, V., \& Akkemik, K. A. (2017). Materialism and fashion consciousness: The moderating role of status consumption tendencies and religiosity. Journal for the Scientific Study of Religion, 56(3), 498-513. doi: https://doi.org/10.1111/jssr.12363 
Yousaf, S., \& Shaukat Malik, M. (2013). Evaluating the influences of religiosity and product involvement level on the consumers. Journal of Islamic Marketing, 4(2), 163-186. doi: https://doi.org/10.1108/17590831311329296

Zaman, A. (2014). Islam versus economics. In Handbook on Islam and Economic Life. Cheltenham, UK: Edward Elgar Publishing. doi: https://doi.org/10.4337/9781783479825.00008

$* * * * * * * * * * * * * * * * *$ 